\title{
A Longitudinal Case Study of a School- University Partnership for Training Teachers
}

\author{
Susan M. Tracz, California State University, Fresno \\ Paul Beare, California State University, Fresno \\ Colleen Torgerson, California State University, Fresno
}

\begin{abstract}
Changing teacher preparation to establish school-university partnerships can help candidates develop teacher identities and exceptional skills by providing supportive experiences in challenging situations. Focus groups and interviews were conducted with student teachers, teachers, principals, and program directors from a school-university partnership at its inception and seven years later. Five themes emerged: 1) change from individualistic to collective perspectives, 2) family-like, emotional support and collaboration, 3) intensive student teacher initiation, 4) professional development and reward systems, and 5) interconnectedness and accountability to multiple persons and supervisors.
\end{abstract}

Keywords: school-university partnership, teacher preparation, teacher identity, student teacher initiation, collective perspectives

It can be argued that the basic charge of teacher education programs is to help each prospective candidate develop an identity as a teacher (Beauchamp \& Thomas, 2009; Freese, 2006; Hammerness, DarlingHammond, \& Bransford, 2005; Smagorinsky, Cook, Moore, Jackson \& Fry, 2004). This maturing identity changes as a young person contemplates a career as a teacher; earns an undergraduate degree and matriculates through a teacher education program and a student teaching experience; embarks on a vocation as a novice teacher; and evolves into an experienced, effective teacher who can complete the cycle by assisting the profession with the induction of new teachers. Rodgers and Scott (2008) posited that various teacher identity constructs share four basic assumptions: 1) "identity is dependent upon and formed within multi- ple contexts," which include schools, classrooms, families, universities, and communities; 2) "identity is formed in relationships with others and involves emotions"; 3) "identity is shifting, unstable, and multiple"; and 4) "identity involves the construction and reconstruction of meaning through stories over time" ( $p$. 733). Given the importance of these assumptions, further exploration is needed, especially in the context of school-university partnerships.

The impact of context on teacher identity is complex, varied, and changing. It also can seem contradictory, but numerous contexts must be negotiated for a teacher candidate to be empowered as both currently effective and open to change and growth. For example, a teacher candidate may believe s/he taught a creative, caring, and innovative lesson on social justice, yet may come to have conflict with a school administration that may hold differing yet valid perspectives on the topic. The developmental task for teacher candidates here is to hold a personal identity that allows for multiple ways to interact within social, cultural, religious, familial, political, and other contexts while preserving their integrity or "conscious weaving together" (Palmer, 1998; Rodgers \& Scott, 2008, p. 738) of complex and diverging milieus.

It follows that teacher candidates, who are placed in various contexts, are in deep and meaningful relationships with their master teachers, university instructors, fellow teacher candidates, students, other teachers, principals, parents, and many others, all while they are trying to grow and prove themselves. It also follows that they will have emotional reactions in these relationships. Hargreaves (2001) referred to these relationships as "emotional geographies" (p. 1061). As a result of these relationships during teacher training, identity is co-constructed (Smagorinsky et al., 2004), and the importance of facilitating bonding 
and eliminating destructive emotional experiences cannot be overemphasized (Rodgers \& Scott, 2008). Emotional distance, lack of administrative communication and support, and lack of collaborative networking may even be causes for high rates of teacher attrition (Borman \& Dowling, 2008; Futernick, 2007).

The fact that identity constantly changes and reflects multiple roles is a compelling reason for instituting teacher education programs, which can guide that development. When the teacher candidate assumes a particular role and his/her identity aligns, that person experiences a sense of congruity, but when roles and identities are misaligned, discord ensues (Sexton, 2008). Besides gaining emotional maturity by successfully juggling multiple, changing roles and mastering skills like classroom management and effective lesson creation, teacher candidates are also expected to cultivate a professional identity (Beauchamp \& Thomas, 2009; Freese, 2006). The professional knowledge teachers craft and acquire includes subject matter knowledge, pedagogical knowledge, and didactical knowledge, and all are necessary for successful teaching (Beijaard, Verloop \& Vermunt, 2000). In the midst of overload from gaining new knowledge and conceptualizations and practicing skills in ever-changing classrooms, the process of negotiating a fluid and dynamic identity depends on a teacher candidates' ability to reflect and find his/her own unique voice (Rodgers \& Scott, 2008).

Despite, or perhaps because of, the varied contexts, emotional relationships, and multiple roles that teacher candidates experience in their induction, the construction of stories allows for the emergence of voice and also contributes to the development of agency (Rodgers \& Scott, 2008; Sexton, 2008). Stories are created from identity, and conversely, identity is formed by stories. These stories or narratives allow teachers to process their identities or employ a type of formative self-evaluation, which is facilitated by self reflection over multiple, changing professional and emotional contexts. Not surprisingly, most literature on teacher identity centers on the identity of the self. However, discourse arising from storytelling is a form of social or collective engagement, and teaching is a public and collaborative endeavor--especially at partnership schools--so the impact of the collective voice or the community of the school calls to be examined as an aspect of identity and teacher training. Wenger (1998) discussed the pervasive effects of community on identity. Sfard and Prusak (2005) wrote that storytelling is collective and powerful, and this sense of the collective community continues to be crucial as teachers develop through their careers (Hold, 1997).
Despite the unique characteristics of these four assumptions about teacher identity, they are inextricably intertwined, and the challenge for teacher preparation programs is to provide contexts that offer supportive opportunities and fertile ground for teacher candidates to reflect and develop their own stories, voices, and agencies. Smagorinsky et al. (2004) called for teacher induction programs to place students in situations that would challenge them to question their identities and beliefs. Daloz (1999) postulated that both support and challenges are necessary for positive change to occur. The author explained that low challenge coupled with low support results in stasis, while low challenge coupled with high support ends in confirmation, and high challenge with low support creates retreat. It is only the combination of high challenge and high support that brings about growth (Daloz, 1999). But the real question is not about the identity that each teacher candidates will assume; it is "the black box of how" candidates will become teachers and how teacher education programs can "facilitate this process" that is important (Rodgers \& Scott, 2008, p. 733).

Most teacher preparation programs follow a similar sequence of activities related to degree, license, or credential requirements. These include earning a bachelor's degree, which is done either in conjunction with taking a series of teacher education courses or immediately followed by a post-baccalaureate experience consisting of approximately the same series of education courses that culminates in student teaching (National Council for Accreditation of Teacher Education [NCATE], 2010). While covering pedagogical and subject matter knowledge, many teacher education programs offer these courses as separate entities that are only weakly connected to each other and involve little actual work in schools until student teaching.

However, the traditional view of university faculty as experts guiding the work of school practitioners is long past (Heafner, McIntyre, \& Spooner, 2014). Beauchamp and Thomas (2009) argued that "alternate forms of interaction within educational contexts need to be promoted" (p. 186). School-university partnerships constitute such an alternative. Well-integrated clinical work taught in the context of schools creates field-based learning that challenges candidates to rethink deep-seated pedagogical and content orientations, bridges methods course content with practice through aligned school-university partnerships, and emphasizes a more in-depth understanding of teaching and learning (Cole \& Knowles, 1993). Partners design clinical experiences of sufficient depth, breadth, diversity, coherence, and duration to ensure 
that candidates demonstrate their developing effectiveness and positive impact on all students' learning and development.

In 2010, the National Council for the Accreditation for Teacher Education (NCATE, 2010) published its report Transforming Teacher Education Through Clinical Practice, calling for dramatic changes in teacher preparation. The report urged a move from academic courses loosely linked to school-based experiences to programs fully grounded in clinical practice that are interwoven with academic content and professional courses. Teacher education programs are asked to redesign their offerings in partnership with school districts and to have shared decision-making and oversight on candidate selection and completion. NCATE was recently replaced by the Council for the Accreditation of Educator Preparation (CAEP, 2013), which calls for even stronger partnerships with explicit language in its standards.

The accreditation agencies are not alone in calling for more partnerships, with both national teachers unions (American Federation of Teachers, 2012; National Education Association, 2014) and the Council of Chief State School Officers (2012) advocating for stronger clinical preparation. The National Research Council (2010) noted that research points to strong field experiences as a critical ingredient needed to prepare effective teachers.

There is still a need for research to document effective practices in clinical partnerships (Larson \& Kyle, 2014) and determine what factors lead to their success. Improvements can manifest themselves in a variety of ways including improved student achievement, powerful professional development opportunities for classroom teachers, and unique opportunities for undergraduate teacher candidates to learn their craft in a nurturing environment (Darling-Hammond \& Baratz-Snowden, 2005). School principals, district leaders, university professors, and candidates, however, have differing ideas on why partnerships are successful and what should go into such collaborations. Building and sustaining quality professional development schools can be a challenge, thus valid models for such practice are needed (Doolittle, Sudeck, \& Rattigan, 2008). Echoing Rodgers and Scott's (2008) call to answer the more general question of "how," Cbulka (2014) wrote that the challenge is to identify how specific clinical practices and features of preparation programs produce effective teachers for today's diverse learners. A research agenda is needed to identify the attributes of strong partnerships so they can be replicated and the field of teacher preparation can be improved.

\section{Purpose}

Therefore, the purpose of this longitudinal case study was to document and describe stakeholder reactions to and beliefs about a school-university partnership and its evolution from its inception to its current operation. To do so, this research utilized a pragmatist theoretical framework. Pragmatism seeks to identify what is effective rather than the abstract concept of what is true (Mertens, 2005; Patton, 2002; Tashakkore \& Teddlie, 2003), and this research sought to learn what stakeholders believed was effective for this partnership.

\section{Methods}

\section{Design}

This longitudinal case study research consisted of two phases of data collection. The initial or early phase of data collection took place nearly 10 years ago, which was shortly after the partnership was created but after its expansion beyond the first cohort. The later or established phase of data collection occurred between seven and eight years later.

\section{Context of Location and Partnership}

Central State University (pseudonym, CSU) is located in a relatively large city in the United States, but this location is also a very economically challenged city with one of the lowest median family incomes in the nation (Kurtzleben, 2011). The Brookings Institute ranked the city as one of the highest in the U.S. for concentrated urban poverty (Simmons, 2005). The city's population is around 50\% Hispanic, 30\% White, 10\% Asian, and 5\% Black (Brookings Institute, 2015). Nearly $30 \%$ of the residents are foreign born.

The elementary teacher preparation program at CSU is both state and NCATE accredited. The current 34-semester unit program is sequenced so it may be completed in a calendar year (summer, fall, spring), but it is typically completed in $1 \frac{1}{2}$ years (e.g., fall, spring, fall). The classes were designed to meet state and national standards, researched practices and theories, state teacher expectations, dispositional attributes, and skills identified by local districts as critical to professional success. Each course syllabus may be enhanced but not changed by faculty. Required courses include:

- Understanding the Learner,

- Instructional Design and Assessment,

- Cultural and Language Contexts of the Classroom,

- Teaching Reading and Social Studies in Grades 4-8, 
- Field Study A (10 hours per week, 15 weeks), - Science Instruction and Applied Technology,

- Math Instruction and Applied Assessment,

- Teaching Reading and the Arts in Grades K-3,

- Field Study B (15 hours per week, 18 weeks),

- Differentiated Instruction and Classroom Management, and

- Field Study C Final Student Teaching (full time, 18 weeks).

The three fieldwork courses are embedded, requiring candidates to turn theory into practice through implementation of new strategies and pedagogical skills each semester. Candidates are placed in three settings crossing both primary and upper elementary grade placements, and all are placed in schools with a significant population of English Learners and high levels of poverty.

\section{Central School-University Partnership Program (CSUPP)}

CSUPP is a partnership between CSU and eventually five local school districts of varying sizes. University coursework for a cohort of student teachers is completed onsite in a dedicated classroom at a lead partner school, and cohort members branch out to complete fieldwork experiences in classrooms in other partner schools in that district. The university and participating districts serve as partners striving to affect student learning, educator preparation, professional development, curriculum development, and research. University faculty teaching at CSUPP are paired with district staff who assist in aligning credential courses to procedures and methods used in the district. They are encouraged to team to present coursework and model effective practices in the K-12 classroom.

The candidates attend the same professional development activities as district teachers during the year and start the experience with a day of outdoor team building activities. Each partnership school has an assigned university faculty liaison who receives one course release to work with teachers and candidates at the partner schools, handle logistical difficulties, and assure strong communication between the district and the university. Liaisons teach one course in the program and provide some, but not all, university supervision of candidates.

Currently all students matriculate through the partnership program, but at its inception, only one cohort was formed. Before the partnership creation, fieldwork experiences were minimal, unconnected to courses, and different across sections. At that time, all teacher education courses were taught on the univer- sity campus. Table 1 compares major logistical and curricular differences between former on-campus and current partnership courses of study.

\section{Participants}

This study began once the partnership expanded beyond a single cohort. In the first phase of data collection, an effort was made to interview the population of all partnership stakeholders. Not all of those student teachers, master teachers, or principals were able to attend focus groups scheduled by school liaisons, but most did. In the second phase of data collection, volunteers were approached from the same districts that participated in the initial data collection. This was done to enable an accurate description of the long -term development of the partnership. Again, all stakeholders were invited to participate in focus groups scheduled by liaisons, though not all volunteered to do so. Table 2 provides information on types and numbers of participants, districts, and focus groups and interviews. A total of 94 student teachers, master teachers, principals, and university partnership directors were interviewed for this case study research. Student teachers were representative of CSU's demographics, which was 35\% English learners when they attended K-12, 66\% first generation college students, $70 \%$ from an under-represented group, and $66 \%$ with a high school GPA under 3.0.

\section{Instrumentation}

Separate semi-structured interview protocols were used for student teachers, master teachers, principals, and directors. In an effort to document the changes that occurred in the partnership, the same protocols were used for initial and later data collection phases. These are summarized in Table 3. Questions attempted to gather information about participant experiences in the partnership, partnership effects on teacher training, and partnership logistics.

\section{Data Collection and Analysis}

The data source consisted of fifteen participant focus groups and one interview. The initial or early phase of data collection took place in the second semester after the partnership was established. The later or established phase of data collection occurred over three semesters seven to eight years later.

This study went through the IRB process. The participants were contacted by the university liaison and asked if they would agree to be interviewed. All student teachers, master teachers, principals, and directors completed consent forms indicating they agreed to be interviewed and audio-recorded. Master teachers were each given a $\$ 20$ gift card after the focus 
Table 1

Logistical and Curricular Adaptations of Credential Program for CSUPP Teacher Candidates

\begin{tabular}{|c|c|}
\hline Campus based (Prior to partnership) & Partnership \\
\hline \multicolumn{2}{|c|}{ Logistical adaptations } \\
\hline Not sequenced & $\begin{array}{l}\text { Sequenced courses, tied to fieldwork and peda- } \\
\text { gogy classes }\end{array}$ \\
\hline Classes on campus & All classes on site in partnership school \\
\hline Course taught with faculty lens & Course taught with district lens \\
\hline Single professor plans and teaches course & $\begin{array}{l}\text { P12 and University faculty co-plan course and } \\
\text { deliver through team-teaching }\end{array}$ \\
\hline Candidates not assigned to PLC for the year & Candidates part of PLC for the year \\
\hline Field work in as many as three districts & Field work in one district \\
\hline $\begin{array}{l}\text { Co-teaching utilized as model for clinical prac- } \\
\text { tice }\end{array}$ & $\begin{array}{l}\text { Co-teaching utilized as model for clinical prac- } \\
\text { tice }\end{array}$ \\
\hline Master teacher for each field experience & $\begin{array}{l}\text { Clinical fieldwork team includes Liaison teach- } \\
\text { er from University and Mentor teacher from } \\
\text { district in addition to master teachers }\end{array}$ \\
\hline $\begin{array}{l}\text { University only interviewing and selection for } \\
\text { the program }\end{array}$ & $\begin{array}{l}\text { Joint P12 and University interviewing and se- } \\
\text { lection for the program }\end{array}$ \\
\hline $\mathrm{N} / \mathrm{A}$ & $\begin{array}{l}\text { Special programs to meet target needs of dis- } \\
\text { tricts }\end{array}$ \\
\hline Recruitment by University & Recruitment by districts and University \\
\hline $\begin{array}{l}\text { Candidates present when University is in ses- } \\
\text { sion }\end{array}$ & $\begin{array}{l}\text { Candidates present at beginning and end of } \\
\text { school year }\end{array}$ \\
\hline \multicolumn{2}{|c|}{ Curricular applications } \\
\hline Department only approves syllabi & Joint planning and approval of syllabi \\
\hline $\mathrm{N} / \mathrm{A}$ & $\begin{array}{l}\text { University faculty teach model lessons in the } \\
\text { partnership schools }\end{array}$ \\
\hline $\mathrm{N} / \mathrm{A}$ & Shared professional development \\
\hline $\mathrm{N} / \mathrm{A}$ & $\begin{array}{l}\text { University and P12 faculty rounds } \\
\text { (walkthroughs) }\end{array}$ \\
\hline
\end{tabular}

groups were completed, but they did not know about this token of appreciation prior to the interviews. The director in the later phase is an author on this paper.

The focus groups were planned by the university liaisons to fit the schedules of the student teachers, teachers, and principals. The interviews lasted between 45 and 110 minutes, and all were recorded. All interviews took place at school sites in classrooms or common rooms, such as the teacher's lounge, with those involved sitting comfortably around tables. The first author conducted all interviews and frequently went off protocol to probe deeper into topics of interest. All recordings were transcribed to provide text data for this study.
The constant comparison and analytic induction methods were used to identify emerging themes (LeCompte \& Preissle, 1993; Merriam, 2009). First, separate coding was done for text data from student teachers, master teachers, principals, and directors. Later, coding across participant types was collated. This process served as a type of triangulation as responses from different categories of participants were compared. Responses were generally consistent. To establish trustworthiness, member checking was done with teachers, principals, and directors, who agreed with the themes and conclusions. Member checking was not done with the student teachers. Although all student teachers signed informed consent forms, in an effort to elicit accurate information that was not in- 
Table 2

Focus Group and Interview, Participant, and District Information

\begin{tabular}{cc}
\hline Early data gathering & Later data gathering \\
\hline Student Teachers & Student Teachers \\
6 focus groups & 3 focus groups \\
3 districts & 3 districts \\
26 student teachers & 32 student teachers \\
& \\
Master Teachers & Master Teachers \\
2 focus groups & 2 focus groups \\
2 districts & 2 districts \\
13 master teachers & 13 master teachers \\
& \\
Principals & Principals \\
1 focus group & 1 focus group \\
2 districts & 1 district \\
3 principals & 4 principals \\
& \\
University Director & University Director \\
1 focus group & 1 interview \\
2 co-directors & 1 director \\
\end{tabular}

tended to impress the interviewer, the researcher did not ask for names during interviews and did not connect names of individual student teachers with specific transcribed text. Since data was collected late in their programs, these student teachers could not be contacted later for the member checking process.

\section{Results}

All participants offered important insights about the development and implementation of the partnership and its effects on them and their students. Five interlocking themes were identified: 1) change from individualistic to collective perspectives, 2) family-like, emotional support and collaboration, 3) intensive student teacher initiation, 4) professional development and reward systems, and 5) accountability to multiple persons and non-supervisors. These themes included many aspects related to the assumptions about teacher identity as will be discussed below.

After these five themes emerged, they were discovered to match with Hord's (1997) system of professional learning communities. This information is presented in Table 4. An important finding of this study is that establishing partnerships with schools for training student teachers parallels the establishment of professional learning communities for teachers.

\section{Change of Individualistic to Collective Perspectives}

One of the trends notable in the partnership over time from its inception to its current modus operandi is the change from individualistic to collective perspectives for all stakeholders. This change toward collectivist and collaborative teaching approaches is probably attributable at least in part to establishment of professional learning communities (PLCs) at each of the participating schools, which was bookended by the two data collection timeframes, rather than the partnership exclusively. However, mutually agreed upon practices and logistics decided on for the partnership reinforced that spirit of collaboration. The transformations in teachers and their relationships with each other and their profession at each school began with development of PLCs, and it continued to include student teachers as viable and active members of the school culture.

Both early and later directors reported that the university dean, who is an author of this paper, was the genesis of the idea and the vision of the partnership, along with the driving force in its establishment. The dean initiated talks with several local school district superintendents who were receptive to the concept. Like-minded faculty were included in these discussions, and later a consultant was brought in to help develop goals and a memorandum of understanding. As superintendents and principals saw the value of the partnership, demand for more partnership schools grew. One partnership director stated,

The vision is this bigger picture of collaboration and trying to find ways to access resources from 
Table 3

Focus Group/Interview Protocol Questions/Content by Student Teachers (ST), Teachers (T), Principals (P), and Directors $(D)$

\begin{tabular}{|c|c|c|c|c|}
\hline Questions/Content & ST & $\mathrm{T}$ & $\mathrm{P}$ & $\mathrm{D}$ \\
\hline 1. Why choose Central School-University Partnership Program? & $\mathrm{X}$ & & & \\
\hline Would you choose to be in CSUPP again? & $X$ & & & \\
\hline \multirow{2}{*}{$\begin{array}{l}\text { 2. Expectations about CSUPP } \\
\text { Hope/fear about CSUPP; Expectations match/differ placement }\end{array}$} & $\mathrm{X}$ & $\mathrm{X}$ & $x$ & \\
\hline & $\mathrm{X}$ & & & \\
\hline \multirow{3}{*}{$\begin{array}{l}\text { 3. Level of Student Teacher preparation } \\
\text { Well-prepared for own classroom \& classroom management } \\
\text { Well-prepared to teach English Learners }\end{array}$} & & $\mathrm{X}$ & $X$ & \\
\hline & $X$ & & & \\
\hline & $\mathrm{X}$ & $\mathrm{X}$ & $X$ & \\
\hline \multirow{4}{*}{$\begin{array}{l}\text { 4. CSUPP effects on student teaching } \\
\text { Feedback ST got during student teaching; Other help for ST } \\
\text { Teacher contributions to ST preparation } \\
\text { Time \& quality of teacher \& ST feedback \& communication }\end{array}$} & $\mathrm{X}$ & & & \\
\hline & $x$ & & & \\
\hline & & $X$ & & \\
\hline & & & $X$ & \\
\hline 5. ST schedules \& assignments; pulling students out of class & & $\mathrm{X}$ & $\mathrm{X}$ & \\
\hline \multirow{5}{*}{$\begin{array}{l}\text { 6. Teacher topics/concerns } \\
\text { Teacher knowledge of CSUPP expectations; teacher orientation } \\
\text { Additional training teachers would find helpful } \\
\text { Meeting teacher needs; Incentives for teachers } \\
\text { Teacher recruitment; qualities looked for in teachers }\end{array}$} & & & $\mathrm{X}$ & $x$ \\
\hline & & & $\mathrm{X}$ & \\
\hline & & & $x$ & \\
\hline & & & & $\mathrm{X}$ \\
\hline & & & & $\mathrm{X}$ \\
\hline \multirow{3}{*}{$\begin{array}{l}\text { 7. Benefits } \\
\text { Benefits of having a ST, being in CSUPP } \\
\text { CPET district, principal \& district administrator benefits }\end{array}$} & & $x$ & $x$ & $x$ \\
\hline & & $x$ & $X$ & \\
\hline & & & & $X$ \\
\hline \multirow{3}{*}{$\begin{array}{l}\text { 8. Challenges/hindrances } \\
\text { Challenges/hindrances of having a ST, being in CSUPP } \\
\text { CPET district, principal \& district administrator challenges/ } \\
\text { hindrances }\end{array}$} & & $x$ & $x$ & $x$ \\
\hline & & $X$ & $X$ & \\
\hline & & & & $x$ \\
\hline \multirow{3}{*}{$\begin{array}{l}\text { 9. Support } \\
\text { Support teachers and principals want from university } \\
\text { Support university gains from teachers, schools \& districts }\end{array}$} & & $X$ & $X$ & \\
\hline & & $X$ & $X$ & \\
\hline & & $X$ & $X$ & \\
\hline \multirow{3}{*}{$\begin{array}{l}\text { 10. State of CSUPP } \\
\text { Current state of CSUPP } \\
\text { How can CSUPP change/improve? "Long haul” needs? }\end{array}$} & & & $X$ & $X$ \\
\hline & & & & $x$ \\
\hline & & & $X$ & $X$ \\
\hline \multirow{5}{*}{$\begin{array}{l}\text { 11. Director topics/concerns } \\
\text { Guiding ideas and principles for initiating CSUPP } \\
\text { Choosing CSUPP districts; qualities looked for in districts } \\
\text { Logistical challenges in starting the partnership } \\
\text { CSUPP progress toward NCATE Partnership School Standards }\end{array}$} & & & & $X$ \\
\hline & & & & $X$ \\
\hline & & & & $X$ \\
\hline & & & & $X$ \\
\hline & & & & $X$ \\
\hline
\end{tabular}


Table 4

Comparison Between the Themes from This Partnership Study and Hord's Professional Learning Communities

\begin{tabular}{ll}
\hline Themes from Partnership Study & Hord's PLCs \\
\hline Change from individualistic to collective perspectives & Shared values and vision \\
Family-like, emotional support and collaboration & Supportive conditions \\
Intensive student teacher initiation & Shared practices \\
Professional development and reward systems & Collective learning \\
Accountability to multiple persons and non-supervisors & Shared leadership
\end{tabular}

Source: Hord, S. M. (1997). Professional learning communities: Communities of continuous inquiry and improvement. Austin, TX: Southwest Educational Development Laboratory.

multiple areas including the community, the district, and the university ... [because] it was going to be beneficial to the school district and the university to have those kinds of connections including working with our teaching candidates.

During the time between the initiation of the partnership when data were first collected and the later phase of data collection, all partnership schools independently began PLCs as a form of professional development with the ultimate goal of improving student learning. The PLCs fostered a remarkable shift from individualistic towards collective perspectives, which was dramatically evident in the changes in teacher language. Initially, teachers spoke in first person singular. For example, one teacher remarked, "I have an hour to do science and history." Also, teachers initially spoke about autonomy in their classrooms, stating, "I made my student teachers do everything. I made them come on Fridays sometimes. I made them take over the morning work. I made them just do lessons. I would model it, and I would watch them do it."

Later teachers spoke in first person plural to express their newfound collective identity and indicated their collective responsibility for all students. One teacher's commented, "We'll be there to help them," and another added, "I know all the 3rd graders. We [3rd grade teachers] all take care of them." The importance in the shift in language usage from singular to collective pronouns cannot be overestimated, as it was pervasive and illustrates a profound sharing of values, vision, identity, and purpose.

This collective duty of teachers for students and for work on instruction expanded to their expectations for student teachers. Teachers used military metaphors to describe how they viewed their work as collectively accomplishing goals, declaring, "When we have assemblies, we deploy the student teachers where we need them, even if they have assignments in other grades." As a result, student teachers learned not only to take responsibility for all students, but also that they collectively could expect caring support from all teachers. An appreciative student teacher remarked, "We feel comfortable. So I'm comfortable asking any teacher around here for help with anything [and] not just to go to my master teacher." This sharing of responsibilities for students and student teachers is indicative of PLC work. It provides foreshadowing of co-teaching and represents an example of educators assuming multiple roles and a real shift in the identities and values of teachers.

\section{Family-like, Emotional Support and Collaboration}

Hord (1997) and Hord, Bradley, and Roy (2013) described supportive conditions as having two components. The first involves structural and physical conditions for support, such as having time and a place to meet. The second is relational and involves teamwork and human capacity, much like the assumption about meaningful relationships (Rodgers \& Scott, 2008). As the partnership schools were started and developed, logistic issues arose, as happens with any organization, and they were dealt with in a cooperative and inclusive manner that enhanced the trust, collaboration, and support between all parties.

After the initial agreements were reached, the logistics of this program needed to be worked out. Although close relationships between the dean and the superintendents were the seeds of this collaboration, it was recognized that buy-in was needed from principals, teachers, and faculty members. The sought-after qualities for inclusion in the partnership were vision, openness, flexibility, and sensitivity. But at times districts chose particular schools to participate due to the characteristics of those schools. 
Once schools were chosen, other logistical matters needed to be worked out. Since classes were to be offered on school campuses, space, which is always at a premium, needed to be provided by the school. One student teacher expressed concern: "I just didn't know how we were all going to fit into that tiny room." The director summarized the space issues by noting, "Initially we were looking for them to be open to having us on their campus and partnering to allow us to use their space."

A critical component in the partnership was the assignment of a university director and a university liaison to coordinate other logistical concerns such as rooms, schedules, student assignments, and teacher participation. As roles became clear and teachers and all participants learned expectations of themselves and others, mutual trust grew. For example, teachers learned that the liaison would tell student teachers what to wear if their attire was inappropriate, and the teachers appreciated this, as they did not think that type of communication was part of their job. Likewise, university faculty appreciated the opportunity to have access to classrooms to give demonstration lessons, which teachers also welcomed.

The family-like, emotional support and professional collaboration that occurred in the partnership was instrumental in the development of student teacher skills and their teacher identities as well as the program's success. When the partnership was initiated, it was a top-down model that required the recruitment of student teachers to become viable. Early phase student teachers, when asked, offered multiple reasons for enrolling in the partnership program. These were usually logistical reasons, such as the convenience of the location or a schedule that allowed them to keep their jobs or pick up their own children after school. In fact, initial student teachers often did not know what to expect of this new arrangement, and some were apprehensive. One student teacher stated, "I just came in blindfolded." Another commented, "I was just open for anything. I knew it was new, so I knew we were going to kind of be guinea pigs, so I don't think I really had any expectations." Other student teachers were concerned that cohort members might not get along or might get into a "high school mentality." A student teacher anxiously questioned, "I'm going to be with these people for three semesters, and what if we don't get along?"

By the later phase, student teachers gave very different reasons for choosing to be in the partnership program. They described the experiences of nonpartnership student teachers as just going to classes on the university campus in the evenings and leaving when class was done with no time to interact with other student teachers or develop relationships with them. One student teacher described, "It's not like you're at a [partnership] school, you do your stuff, and you leave, and you never associate with anybody else. It's like it's really a community that we've built [at the partnership School]."

In fact, later student teachers cited strong emotional "camaraderie" and "support" as the predominant reasons for choosing to be in the partnership. Study participants, including student teachers, master teachers, and principals, all described themselves as being so close that they were part of a "family." One student teacher said, "We've bonded. We've grown as one big family. We're all here to help each other," and a master teacher added, "These student teachers have lunch together every day, and they're just like a big family." A principal explained the "family" phenomenon:

You see them taking that ownership of being part of the school family and environment, showing up to carnivals and Friday night movie nights with their families, and they're part of that school. That's something they're not asked to do or have to do, but they take pride and when they come back and their duties are over, those kids model them like they're rock stars.

It may be that the strong, emotionally supportive relationships built among all participants in partnership schools can foster a collaborative teacher identity and serve as a buffer against isolation and thoughts about leaving the profession that lead to the high attrition rates for new teachers. One student teacher declared, "If we hadn't had a cohort, I think probably I would have quit."

In another instance that the researcher only learned after much probing, a student teacher described a difficult situation involving a child with numerous behavioral problems and the child's parent. In her narrative, she explained that it was the emotional support from her master teacher and her fellow student teachers that stopped her from "dropping out" of the profession and that helped her to learn from this experience, thus chronicling how her voice and sense of agency evolved and improved. The student teacher recounted,

I've had a behavior issue with a kid all semester long ... but at a meeting with mom, the boy and mom blamed it on me and said I' $m$ the reason he sits there and doesn't do his work because "I hate him." ... [but] I joke with him. I'll complement him on his outfits or anything positive ... It was 
just so bizarre because he claims to not have problems with the master teacher, when the master teacher pointed out that he's the one who's written him on the contract every time... yet it's all my fault for some reason, so having to deal with these issues, that really put me down, and I really didn't want to do this anymore, but I was reminded by my master teacher and the others why I'm here, and the last two semesters, I had the most amazing experiences ... I felt I learned so much from that and then to go to this experience for me, it was so negative, but now I'm turning it around to a positive learning experience.

By the established phase of this study, the reasons that student teachers gave for choosing to be in the partnership all centered on the intensive, emotional, and academic support they received and the superior learning they had as a result. A student teacher expressed a common reaction:

It was very positive because ... we knew each other personally inside and outside the classroom, which I think really helped a lot seeing as this program is pretty strenuous and we kind of needed each other to lean on.

Another student teacher added,

I feel like we're getting support from the teachers here as well, but not only are we getting support from each other, not only are we getting support from our faculty, from our teachers, but we're getting support from our master teacher and all of the other teachers. I am getting support from everyone in second grade, right. You know, all the second grade teachers, I kind of feel like I need to go and buy all of them a gift when I leave because everyone's been so helpful ... just tons and tons of extra help and support and concern and care.

Interestingly, this environment of academic support and emotional care led student teachers to question the viability of other systems for training teachers. A student teacher explained the difference between the partnership and other teacher training experiences:

Because I had two friends. One didn't do a partnership and one did. That was just a whole big deal of difference, all the things that they experienced. And you notice it once you're done, once you look back on it. Like, 'What did I learn? What did I take from it?' And I can say that when I was in the partnership cohort, I took out more, had more to say, had more to look back on positively. And the friend, I mean I've never seen him teach or anything, but he just regrets it. He wishes he could have done the partnership because there was that time when he had questions, and none were answered ... And he succeeded, but not the way he wanted.

\section{Intensive Student Teacher Initiation}

The immersion and initiation of student teachers into the profession and the school culture is a ritual that most teachers remember for their entire lives. The purpose of initiation rites is to guide the initiate into a new identity, and the partnership serves as an intensive initiation and immersion into school culture and practices that aids student teachers in the development of their new identity as a teacher. The typical student teacher day starts when school starts. In the mornings, student teachers are in classrooms observing at first, then performing supporting duties, and finally taking over the classroom completely. Partnership student teachers all have lunch together, usually engaging in constant discourse about their experiences of the day or working together on assignments for the courses they are taking. These courses are also held at the school site and are part of the embedded fieldwork, which adds to the intensive engagement within the school culture. In addition, the student teachers must work individually with elementary school students for their course assignments, prepare their teaching materials, conference with their master teachers and university faculty, and help with other services as needed. It is intense and demanding.

Because the student teachers did everything together, they learned from their own experiences and from each other. Student teachers were vicariously exposed to multiple teachers' approaches, skills, and resources because they shared ideas, experiences, and materials with each other. The growth that student teachers experienced was accelerated because they were exposed to ideas from multiple teachers and guidance was provided in an intensive context. Consequently, collaboration, networking, and professional sharing were internalized more quickly and at much deeper level. Several student teachers provided positive comments:

We learned a lot from each other. We just took each other's ideas and strategies, and we implemented it in our own work and classroom, and that really helped us. We would have conversations about 'What to do with this kid? What should I do with this project?' and so we really collaborated even outside of class. [We] emailed each other: 'Hey, can you help me with this?' We've all learned to work with each other, and I 
feel like just having this positive experience is going to benefit us.

Another remarked,

We're actually, you could say, placed in a lot of different classrooms because we were able to share our experiences ... because some things that happened in the classroom are similar and some of it is different, and then to know that the teachers were different themselves ... hearing how other teachers, other master teachers would handle a classroom management situation. 'My teacher did the best thing today,' and then we'd tell everybody, and then we'd all make a little note, and we have this list of good classroom ideas, and it's impossible for me to go sit in 20 different classrooms, but I got to observe what other teachers did.

Yet another student teacher stated,

If I had a problem in my classroom, I can go to one of us and ask, 'How does your teacher handle this? This is how my teacher handled it.' Even though we were only in one placement, we're actually getting experience from all the other placements and teachers because we had the time to share and talk about it.

Current partnership practices, which exemplify synergistic sharing and collective discourse and posit that multiple teaching practices are viable, sharply contrast with previous, isolationist methods for training student teachers. One principal commented, "When I did student teachers before, they just went to the classroom and the university. They were more isolated. You just closed the door and taught. That was it." Another principal discussed more current procedures:

Five years ago, the way we'd support a student teacher would be fairly basic compared to today, but I think that is because of the capacity of our teachers and our district has grown so much, not to just internalize innovative instruction, but being a part of a PLC, and how to respond when kids aren't learning.

In the years from the initial data collection to the later collection, partnership schools went from having no PLCs to all having active and productive PLCs. This new professional practice gave teachers another venue for sharing their knowledge and practices. However, as in traditional student teacher assignments, partnership student teachers continued to have close working relationships with their master teachers. A strong recurring belief expressed by the master teachers as part of their evolving teacher identity was that they had a "responsibility" to help train the next generation of teachers, and they were serious and rigorous about this duty. The theme of sharing their knowledge of teaching and passing that knowledge on to the next generation was also enhanced as student teachers became members of the PLCs.

In one of the most exuberant descriptions of a positive educational experience, a student teacher described how she shared an idea for teaching a lesson with other grade level teachers at a PLC meeting, they all discussed the idea, and then all the teachers decided to teach the same lesson using the student teacher's ideas. The student teacher voiced a strong sense of humility at her status as a novice along with a sense of honor that the other teachers recognized the value of her lesson ideas. They all shared their practice and the lesson was highly successful. The student teacher's initiation into the profession reached a new level of acceptance and completion with a high degree of satisfaction, which was made possible by supportive conditions.

\section{Professional Development and Reward Systems}

In initial interviews, teachers and principals viewed rewards and incentives as something necessarily external. Teachers expected monetary payment for serving as master teachers, but principals were opposed to this idea, believing that paying master teacher positions would result in a seniority system that would not necessarily result in the best or most capable teachers serving as master teachers. Partnership directors shared the principals' views on this point, and they also were aware of the university's limited ability to pay master teachers. University personnel hoped that offering teachers coursework for reduced cost would incentivize teachers to enroll in the university and ultimately continue their coursework and earn master's degrees.

By the time that the later data was collected, a mindset shift had taken place. Whether this was due to the partnership or not was unclear, but rewards became more internalized and student-focused for student teachers, teachers, and principals alike. Indicating how important knowledge and effective practice was to her, one teacher explained, "I don't want a pat on the back. I want to know, 'OK, How can I make this better? How can it make me a better teacher?' Because that's my goal."

Sharing was also viewed as rewarding. Sharing included assets like time, knowledge, resources, practices, constructive criticism, and recognition for student gains. Sharing was evident in multiple ways 
that led to forms of professional development. Teachers found university modeling of lessons and the most current ideas and information that student teachers provided to be highly valuable. One teacher stated, "I also like the ideas that she [student teacher] has. We always try to stay fresh and on top of things." A student teacher further explained, "Because we're together all the time, we've learned who is strong in what and who is weak in what, and so we were able to pair ... You're good in doing this and I am good in doing this so we can work together." Teachers also appreciated the extra help of having several student teachers in classrooms, which both exhibited a more collaborative teaching practice and anticipated current co-teaching initiatives. A master teacher elaborated, "I'm walking around helping and then I have suddenly 10 hands in the air. It helped to have three adults walking around answering questions, giving that individual help." Not only were rewards internal, they were affective rewards, and quality of teaching practices and student outcomes led to a sense of pride and collegiality that was palpable for all.

\section{Interconnectedness and Accountability to Multiple Persons and Supervisors}

One unique component of the partnership is the different system of accountability that evolved and flattened the hierarchy of leadership, placing student learning at the forefront. Most stakeholders in the partnership system are accountable to people other than their direct supervisors, and this situation about responsibility was pervasive. Student teachers are accountable to everyone including principals, their master teachers, other teachers, university faculty, and liaisons, even if they are not grading or hiring them. Teachers feel responsible for training all student teachers and to university liaisons even if they are not their master teachers or enrolled in university programs. Principals feel accountable to the university for being selected, as being a partnership school is both an honor and responsibility. Finally, university directors, liaisons, and faculty are answerable to district administrators, principals, and teachers, as the gains in achievement for $\mathrm{K}-12$ students must continue despite all the extra activity of simultaneously training student teachers.

\section{Discussion}

From the stakeholder descriptions of their schools, there can be no argument that these were challenging places where teachers had to work hard for their students to learn. From the stakeholder descriptions of the partnership, it is apparent that these were supportive, joyful, and demanding environments. It is also evident that the positive reactions to the partnership only grew and intensified over time. According to Daloz (1999), challenges and supports are both necessary for growth to occur, and all stakeholders would likely agree that this was the case in the partnership. This partnership fulfilled all the assumptions needed for candidates to develop positive teacher identities: multiple contexts, supportive emotional relationships, integration of shifting and varied roles, and the opportunity to tell stories that helped them develop voice and agency (Rodgers \& Scott, 2008). In fact, answering "how" teacher education programs (Cbulka, 2004; Rodgers \& Scott, 2008) can foster development of a teacher identity may be done by studying the characteristics of partnerships as described by the themes of this study.

The themes that emerged in this study shed light on the process of developing a teacher identity in a positive way. In schools and school culture, collaboration and collective perspectives are essential, and they are the backbone of the support and common goals felt by all stakeholders. This is especially true for student teachers, whose teacher identity is in its formative and vulnerable infancy. Being surrounded by professionals with a collective perspective who speak in terms of "we" instead of " $\mathrm{I}$ " is not only empowering and uplifting, but it also makes student teachers feel they belong. Student teachers, master teachers, and principals alike described the support in the various partnership school contexts as "family-like," demonstrating the schools were a place like home and the people could be depended upon. The student teachers needed this support because the initiation process was intensive and not everything they did was successful. Being immersed in a school context where students teachers were at a field site from early in the morning, were in classes all day, ate lunch while sharing experiences and ideas, and went home to prepare for the next day was highly demanding. While being positioned in schools to question their identities and beliefs (Smagorinsky, et al., 2004), student teachers in partnership schools had the advantage of constantly interacting and talking about their experiences, their master teachers, their lessons, their classroom management issues, other master teachers, K-6 students, and various other topics. Their situation was so intensive that they vicariously experienced and learned from their colleagues by telling their own stories and hearing those of others. This was a unique form of professional development for both student and master teachers. Finally, growth in teacher identity began to come full circle, and student teachers grew to feel responsible to serve their own students and many others like all those in the profession that they 
were modeling. What is important to recognize is that this interconnectedness and synergy came from the fieldwork situations that the partnership created, such as on-site coursework, intensive integration into school culture, and collaboration with fellow student teachers.

It is interesting to recognize that the five themes that emerged in this research parallel the five aspects of professional learning communities identified by Hord (1997). Hord wrote that "comprehensive redesign of schools including decentralization, shared decision making, schools within schools, teacher teams and/or professional communities of staff can improve student learning" (p. 30). She also argued that schools that have these characteristics are noted for less isolation of teachers, more commitment to missions and goals, shared responsibility, greater ability of teachers to inspire students, and better student outcomes. Perhaps the collaborative conditions that facilitate successful teacher preparation in partnership schools can enable veteran teachers and university personnel to continually evolve and grow along with the changing times.

\section{Conclusion}

Linda Darling-Hammond (2006), when writing about her earliest teaching experiences, pointed out what everyone who teaches knows: "How incredibly difficult teaching is if you actually want to reach every single student" (pp. ix-x). In the biographical preface, Darling-Hammond continued to discuss her experiences with two different teachers of her first grade daughter. The first teacher classified students as "good" and "bad" and proceeded to impose impossible rules on the bad ones. The second teacher diagnosed her daughter with dyslexia and provided her with a series of interventions that were successfully accomplished without her daughter "ever really knowing that she had a disability" (p. xi). Though both of these teachers were first year teachers, one came from a high quality university teacher training program, and the other did not. This distinction served as the impetus for Darling-Hammond to learn what effective teacher education programs were like and to support the quality training of as many teachers candidates as possible.

Despite arguments that teacher education programs are ineffective and unnecessary, evidence to the contrary is plentiful (Darling-Hammond, 2006). The challenge is to find those programs and program components and to implement them as widely as possible. The CSUPP program is one such effective partnership that promotes development of strong and efficacious teacher identities, supports the acquisition of quality pedagogical and subject content knowledge, and nurtures collaborative practices that sustain teachers over the long haul.

\section{References}

American Federation of Teachers. (2012, December). Raising the bar: Aligning and elevating teacher preparation and the teaching profession. Report of the American Federation of Teachers Teacher Preparation Task Force. Washington, DC: Author. Retrieved from http://www.aft.org/pdfs/ highered/raisingthebar2012.pdf

Beauchamp, C., \& Thomas, L. (2009). Understanding teacher identity: An overview of issues in the literature and implications for teacher education. Cambridge Journal of Education, 39(2), 175-189.

Beijaard, D., Verloop, N., \& Vermunt, J. D. (2000). Teachers' perceptions of professional identity: An exploratory study from a personal knowledge perspective. Teaching and Teacher Education, 16, 749-764.

Borman, G. D., \& Dowling, N. M. (2008). Teacher attrition and retention: A meta-analytic and narrative review of the research, Review of Educational Research, 78(3), 367-409. DOI: 10.3102/0034654308321455

Brookings Institute. (2015). Partnership for attainment: Regional indicators. New York: Metropolitan Policy Program at Brookings.

Cbulka, J. (2014). Foreword: Systematic strategies to create clinically rich teacher preparation. Peabody Journal of Education, 89, 419-422. Retrieved from http://dx.doi.org/10.1080/0161956X.2014.938589

Cole, A. L., \& Knowles, J. G. (1993). Teacher development partnership research: A focus on methods and issues. American Educational Research Journal, 30, 473-495.

Council of Chief State School Officers. (2012, December). Our responsibility, our promise: Transforming educator preparation and entry into the profession (CCSSO Task Force on Educator Preparation and Entry into the Profession). Washington, DC: Author. Retrieved from http://www.ccsso.org/ Resources/Publications/Our Responsibility

Council for the Accreditation of Educator Preparation. (2013). Council for the Accreditation of Educator Preparation Report to the Public, the States, the Policymakers, and the Education Profession. Retrieved from http://caepnet.files.wordpress.com/2013/05/ annualreport final.pdf

Daloz, I. (1999). Mentor: Guiding the journey of adult learners. San Francisco: Jossey-Bass. 
Darling-Hammond, L., with Fickel, Letitia, Koppich, J., Mcdonald, M., Mersith, K., Miller, L., Ruscoe, F., Silvermail, D., Snyder, J. Whitford, B. L., \& Zeichner, K. (2006). Powerful teacher education: Lessons from exemplary programs. San Francisco: Jossey Bass.

Darling-Hammond, L., \& Baratz-Snowden, J. (2005). A good teacher in every classroom: Preparing the highly qualified teachers our children deserve. San Francisco: Jossey-Bass.

Doolittle, G., Sudeck, M., \& Rattigan, P. (2008). Creating professional learning communities: The work of professional development schools. Theory into Practice, 47, 303-310. DOI: 10.1080/00405840802329276

Freese, A. (2006). Reframing one's teaching: Discovering our teacher selves through reflection and inquiry. Teaching and Teacher Education, 22, 110-119.

Futernick, K. (2007). A possible dream: Retaining California's teachers so all children can learn. Sacramento: California State University.

Hammerness, K., Darling-Hammond, L., \& Bransford, J. (2005). How teachers learn and develop. In L. Darling-Hammond \& J. Bransford (Eds.), Preparing teachers for a changing world: What teachers should learn and be able to do (pp.358-389). San Francisco, Jossey-Bass.

Hargreaves, A. (2001). Emotional geographies of teaching. Teacher College Record, 103(6), 1056-1080.

Heafner, T., McIntyre, E., \& Spooner, M. (2014). The CAEP standards and research on educator preparation programs: Linking clinical partnerships with program impact. Peabody Journal of Education, 89, 516-532.

Hord, S. (1997). Professional learning communities: Communities of continuous inquiry and improvement. Austin, TX: Southwest Educational Development Laboratory.

Hord, S., Bradley, J., \& Roy, P. (2013). Deep impact: A learning forward academy graduate inspires learning in her district. Journal of Staff Development, 34(2), 55-57.

Kurtzleben, D. (2011, June 1). Ten cites with the highest and lowest real incomes. U. S. News \& World Report. Retrieved from http://www.usnews.com/ news/articles/2011/06/01/10-cities-with-thehighest-and-lowest-real-incomes

Larson, A. E., \& Kyle, D. W. (2014). Introduction to clinical partnerships in teacher education: Perspectives, practices, and outcomes. Peabody Journal of Education, 89, 415-418. Retrieved from http:// dx.doi.org/10.1080/0161956X.2014.938587
LeCompte, M. D. \& Preissle, J. (1993). Ethnography and qualitative design in educational research (2nd Ed.). San Diego: Academic Press.

Merriam, S. B. (2009). Qualitative research: A guide to design and implementation. San Francisco, JosseyBass.

Mertens, D. M. (2005). Research and evaluation in education and psychology: Integrating diversity with quantitative, qualitative, and mixed methods. (2 ${ }^{\text {nd }} \mathrm{Ed}$.). Thousand Oaks, Sage.

National Council for Accreditation of Teacher Education. (2010). Transforming teacher education through clinical practice: A national strategy to prepare effective teachers. Report of the Blue Ribbon Panel on Clinical Preparation and Partnerships for Improved Student Learning. Washington, DC: Author.

National Education Association. (2014, January). Teacher residencies: Redefining preparation through partnerships. NEA Center on Great Public Schools. Washington, DC: Author. Retrieved from http:// www.nea.org/home/teacher-residencies.html

National Research Council. (2010). Preparing teachers: Building evidence for sound policy. Washington, DC: Author. Retrieved from http://www.nap.edu/ catalog.php?recordid $=12882$

Palmer, P. J. (1998). The courage to teach: Exploring the inner landscape of a teacher's life. San Francisco: Jossey-Bass.

Patton, M. Q. (2002). Qualitative research \& evaluation methods. Thousand Oaks, CA: Sage.

Rodgers, C., \& Scott, K. (2008). The development of the personal self and professional identity in learning to teach. In M. Cochran-Smith, S. FeimanNemser, D. J. McIntyre \& K. E. Demers (Eds.), Handbook of research on teacher education: Enduring questions and changing contexts (pp. 7332-755). New York: Routledge.

Sexton, D. M. (2008). Student teachers negotiating identity, role, and agency. Teacher Education Quarterly, 35(3), 73-88.

Sfard, A., \& Prusak, A. (2005). Telling identities: In search of an analytic tool for investigating learning as a culturally shaped activity. Educational Researcher, 34(4), 145-22.

Simmons, A. M. (2005, October 13). Yosemite's concentration of poor tops in U.S., study says. The Los Angeles Times. Retrieved from http:// articles.latimes.com/2005/oct/13/local/meYosemite13

Smagorinsky, P., Cook, L., Moore, C., Jackson, A., \& Fry, P. (2004). Tensions in learning to teach: Accommodation and the development of a teaching identity. Journal of Teacher Education, 55(1), 8-24. 
Tashakkore, A., \& Teddlie, C. (2003). Major issues and controversies in the use of mixed methods in the social and behavioral sciences. In A. Tashakkori \& A. Teddlie (Eds.), Hand of mixed methods in social and behavioral research (pp. 3-50). Thousand Oaks, CA: Sage.

Wenger, E. (1998). Communities of practice. Cambridge: Cambridge University Press. 